\title{
Taurine Protects Gut Barrier Function and Prevents Endothelial Cell Injury Induced by Ischaemia-Reperfusion
}

\author{
Hong Chen, Gang Chen, Claire Condron* \\ Department of Surgery, Royal College of Surgeons in Ireland Education and Research Centre, Beaumont Hospital, Dublin, Ireland \\ Email: ${ }^{*}$ ccondron@rcsi.ie
}

How to cite this paper: Chen, H., Chen, G. and Condron, C. (2017) Taurine Protects Gut Barrier Function and Prevents Endothelial Cell Injury Induced by IschaemiaReperfusion. Food and Nutrition Sciences, 8, 678-698.

https://doi.org/10.4236/fns.2017.86048

Received: April 29, 2017

Accepted: June 26, 2017

Published: June 29, 2017

Copyright $\odot 2017$ by authors and Scientific Research Publishing Inc. This work is licensed under the Creative Commons Attribution International License (CC BY 4.0).

http://creativecommons.org/licenses/by/4.0/

\begin{abstract}
Purpose: Gut permeability and microvascular injury following ischaemia/reperfusion (IR) have been implicated in the systemic inflammatory response syndrome (SIRS) and multiple organ failure (MOF). Taurine (TAU), a sulfurcontaining amino acid, is a powerful antioxidant and regulator of intracellular calcium and several studies have established that treatment with TAU protects cerebral, cardiac and testicular tissue from (IR) injury. This study investigates the protective effect of taurine in an experimental model of I/R-induced gut injury in rats. Methods: Sprague-Dawley rats were randomized into three groups: Control, I/R, TAU + I/R. TAU was given by gavage or intravenous injection before I/R. Ischaemia was induced by cross-clamping superior mesenteric and coeliac vascular pedicle for $20-30 \mathrm{~min}$, followed by $60-180 \mathrm{~min}$ reperfusion. Gut permeability, blood flux, tissue oedema, leucocytes infiltration and eNOS expression were measured at $3 \mathrm{hrs}$ following reperfusion using FD4. Leukocyte-endothelial interactions were determined by intra-vital microscopy during I/R. In vitro studies assessed the protective effect of TAU on endothelial cell function and survival. Results: Treatment with TAU significantly attenuated IR-induced gut hyper permeability, tissue oedema, leukocyte adhesion and infiltration. TAU also prevented the reduction in gut blood flow, leukocyte rolling velocity and eNOS expression induced by IR. TAU protects against I/R-induced endothelial cell injury by reduced anti-oxidant activity and modulation of eNOS expression and intracellular calcium fluxes. Conclusions: TAU protects the gut from intestinal barrier dysfunction induced by surgical I/R.
\end{abstract}

\section{Keywords}

Ischaemia, Reperfusion, Gut Barrier, Taurine, ROS, Calcium 


\section{Introduction}

Interruption or reduction of blood and oxygen supply to tissue results in cellular dysfunction and death leading ultimately to organ failure. Restoration of blood supply and thereby oxygen to ischaemic tissues; reperfusion, is essential to the survival and recovery of damaged tissue. However, reperfusion may paradoxically induce further cell death [1] and injury in distant organs [2] [3]. In some instances, the degree of tissue damage resulting from ischaemia followed by reperfusion is significantly greater than the injury that results from ischaemia alone [4] [5].

$\mathrm{I} / \mathrm{R}$ injury is characterised by the development of increased microvascular permeability, oedema and tissue necrosis. The injury cascade is mediated mostly by neutrophil-endothelial adherence and subsequent neutrophil-mediated organ damage [6]. Reperfusion of ischemic tissue activates immune cells which produce reactive oxygen species (ROS) and nitrogen species (RNS) in excess, and may induce the systemic inflammatory response syndrome (SIRS), acute respiratory distress syndrome (ARDS), and ultimately multiple organ dysfunction (MODs) [7]. SIRS is particularly common following surgery and the triggers for this complex syndrome are multifactorial. I/R injury and the ischemia-related release of endotoxin from the intestine are implicated [8]. Intestinal I/R injury is a common clinical occurrence in surgery, haemorrhage, trauma, and sepsis, which results in intestinal barrier dysfunction with pronounced mucosal permeability allowing bacterial translocation and the activation of sub-mucosal cells. Infection following abdominal surgery remains a major factor affecting the morbidity of patients. Urinary tract infections, pneumonia, wound infections, intraabdominal abscess and cholangitis are frequently observed among patients undergoing abdominal surgery [9]. Bacterial translocation, the passage of indigenous microorganisms from the intestinal lumen to extra-intestinal sterile sites, plays a significant role particularly for patient undergoing emergency surgery and or who received preoperative total parenteral nutrition (TPN) [10].

The endothelium, a cellular monolayer that forms a vital interface between circulating blood and tissue, not only plays an important role in the regulation of vascular tone and the maintenance of vascular integrity, but is also a major contributor to vessel repair. Vascular endothelial cells (EC) are the initial and prime targets of I/R injury [11]. I/R injury increases intracellular $\mathrm{Ca}^{2+}$ caused either by increased influx of $\mathrm{Ca}^{2+}$ from the extracellular compartment and release from intracellular organelles, or the inability of the cell to extrude $\mathrm{Ca}^{2+}$ as a result of a decreased energy state [12]. The increase in $\mathrm{Ca}^{2+}$ influx activates proteases such as calpains which induce apoptosis [13]. I/R increases ROS production in ECs that directly damages mitochondria and DNA, resulting in cell apoptosis [14] [15] [16]. Nitric oxide (NO) production pathways in ECs are altered during I/R injury resulting in a dramatic increase in leukocytes in post-capillary venules and increased microvascular permeability [10].

Therapeutic interventions initiated at the onset of reperfusion are as effective 
in attenuating I/R injury as treatments introduced during the pre-ischaemic period [17] [18]. Pharmacological targeting of the reperfusion phase offers real therapeutic options for non-elective surgery and could provide vital cytoprotection attenuating inflammatory mediated tissue injury. Taurine, a semi-essential sulphur containing $\beta$-amino acid, attenuates $\mathrm{I} / \mathrm{R}$ and endotoxemia induced tissue injury by scavenging oxygen free radicals, modulating intracellular calcium and inhibiting leukocyte-endothelial interactions [19] [20] [21] [22]. Previous studies from our laboratory have shown that taurine attenuates calcium induced HUVEC apoptosis and necrosis, which is correlated with free radical and peroxynitrite inhibition [23]. Taurine also prevents high-glucose, TNF- $\alpha$ and LPSinduced HUVEC apoptosis through ROS inhibition and modulation of intracellular calcium [24]. Taurine protects against endothelial cell apoptosis and necrosis and corrects endothelial dysfunction in young smokers through an eNOS dependant mechanism [25]. Nakashima et al. demonstrated that taurine protects hepatocytes from cell death induced by hypoxia through a $\mathrm{Ca}^{2+}$ dependant mechanism. Taurine preserves high-energy phosphates during hypoxia maintaining energy-dependent calcium homeostasis [26] and taurine improved cardiac function recovery for prolonged hypothermic rat heart preservation by suppressing DNA oxidative stress and cell apoptosis [27].

This work tests the hypothesis that taurine can augment cellular responses to $\mathrm{I} / \mathrm{R}$ injury in the perioperative period reducing inflammation and end organ tissue damage. Therefore the primary aim of this work is to evaluate taurine as a potential adjunct therapy to surgery in a rodent model of I/R injury.

\section{Methods and Materials}

\subsection{Materials}

Medium 199, Phosphate buffered saline (PBS), P/S/F (penicillin, streptomycin, fungimycin) glutamine, $0.05 \%$ trypsin- $0.02 \%$ EDTA solution and FCS (fetal calf serum) (Gibco Laboratories Paisley, Scotland, UK). Collagenase (type II) (Worthington Freehold, New Jersey). 2\% gelatin, endothelial cell growth supplement, glycerol, taurine, heparin, $\mathrm{NaCl}$, Dextran Hepes, $\mathrm{KCl}, \mathrm{MgCl}_{2}, \mathrm{Glucose}, \mathrm{CaCl}_{2}$, sodium deoxycholate, Triton-100, acrylamide, SDS, Tris, EDTA, ammonium persulphate, TEMED, glycine, bromophenol blue, BSA, Tetrabutylammonium hydroxide (PIC-A) and 2-mercaptoethanol (Sigma ,St. Louis, MO, USA). Fluo-3 $\mathrm{AM}$ and DCFH-DA (fluorescent probe dichlorfluorescent diacetate bis (acetoxymethyl) (Molecular Probes, Eugene, Oregon USA). TACS ${ }^{\circledR}$ Annexin V-FITC Apoptosis Detection Kits (R \& D systems, U.K) Ficoll-Paque ${ }^{\circledR}$ (Pharmacia, Uppsala, Sweden). E-Lyse (Cardinal Associates, USA). FACScan (Beckton Deckinson, Mountain View). 12-well, flat-bottom plates (NUNC, Denmark). Culture flasks (Falcon, Lincoln Park, NJ). Peristaltic pump controller (Masterflex, Cole Parmer Instrument, Co). Bichinoic acid (BCA) protein assay kit (Rockford, Illinois, USA). Mouse antihuman IgG1 eNOS antibody (Transduction Laboratories, USA). Goat antimouse IgG1 conjugated with horseradish peroxidase (DAKO, UK), SuperSignal West Pico Chemiluminescent substrate (Pierce, Rockford, 
USA). CPU 8720, UV/VIS Scanning Spectrophotometer, (Philips, Eindhoven, Netherlands). Laser-doppler monitor (Moor instrument Ltd, England). Intravital microscope (Nikon Diaphot, Tokyo, Japan), 40× objective lens (Flour, Nikon). Video camera (Mitsubishi, CCD-100E, Japan). Monitor (Sony, KVM2150L, Tokyo, Japan) Videocassette recorder (Phillips, VR347, Netherlands).

This study was conducted with the approval of the Beaumont Hospital Ethics Committee. The animal procedures were carried out under license from Department of Health, Republic of Ireland.

\subsection{Cell Culture}

Human saphenous vein endothelial cells (HSVECs) were isolated from human saphenous vein by enzymatic dissociation as described previously [28]. Briefly HSVECs were isolated by placing the vein luminal face down in a shallow Petri dish containing $\mathrm{Ca}^{2+}$ and $\mathrm{Mg}^{2+}$ free phosphate-buffered saline (PBS) and 1 $\mathrm{mg} / \mathrm{ml}$ collagenase type II and incubating at $37^{\circ} \mathrm{C}$ in a humidified $5 \% \mathrm{CO}_{2}$ condition for 15 - 20 minutes. Cells were cultured on $2 \%$ gelatin-coated culture flasks in complete medium 199 supplemented with $20 \%$ FCS, penicillin (100 $\mathrm{U} / \mathrm{ml})$, streptomycin sulfate $(100 \mu \mathrm{g} / \mathrm{ml})$, fungizone $(0.25 \mu \mathrm{g} / \mathrm{ml})$, heparin $(16$ $\mathrm{U} / \mathrm{ml})$, endothelial cell growth supplement $(75 \mu \mathrm{g} / \mathrm{ml})$, and $2 \mathrm{mM}$ glutamine. Cells were growth at $37^{\circ} \mathrm{C}$ in humidified $5 \% \mathrm{CO}_{2}$ conditions and sub-cultured by trpsinization with $0.05 \%$ trpsin- $0.02 \%$ EDTA when confluent monolayer were reached. Endothelial cells were identified by typical phase-contrast "cobblestone" morphology and by the present of von Willebrand factor antigen using the immunofluorescence technique. HSVECs were used in experiments at passages $2-4$.

\subsection{Hypoxia/Reoxygenation and Experimental Protocol}

HSVECs were incubated in the airtight chamber with a gas inlet and outlet (Billups-Rothenburg). A hypoxia microenvironment was achieved by purging the chamber with $95 \% \mathrm{~N}_{2}, 5 \% \mathrm{CO}_{2}$ for 15 min prior to the experiment. The resulting dissolved oxygen concentration in the chamber was $2 \%$. Replacing the HSVEC in humidified $5 \% \mathrm{CO}_{2}$ condition at $37^{\circ} \mathrm{C}$ after hypoxia simulated reoxygenation. HSVECs were cultured to $90 \%$ confluence and plated at $2 \times 10^{5}$ cells per well on $2 \%$ gelatin-coated 12 -well, flat-bottom plates. The final concentration of taurine was $0.5 \mathrm{mg} / \mathrm{ml}[23]$.

\subsection{HSVEC Apoptosis and Necrosis Assay}

HSVECs apoptosis and necrosis were assayed by flow cytometry using the TACS $^{\bullet}$ kit according to the manufacturer's instructions. Briefly, after centrifugation, the pellets of HSVECs $\left(2 \times 10^{5}\right.$ cells $)$ was resuspended in $100 \mu$ fluorochrome solution (Propidium Iodide $10 \mu \mathrm{l}$, Annexin V-FITC $1 \mu \mathrm{l}$ ) and incubated for $15 \mathrm{~min}$ at room temperature in the dark and analyzed by FACScan. The minimum number of 10,000 events was collected and Cell quest ${ }^{\bullet}$ software was used for analysis. 


\subsection{Measurement of Intracellular Reactive Oxygen Species}

ROS in HSVEC was detected by using the fluorescent probe dichloroflurescein diacetate bis (DCFH-DA) as described previously [23]. HSVECs $1 \times 10^{6} \mathrm{cells} / \mathrm{ml}$ were loaded with $20 \mu \mathrm{M}$ DCFH-DA in PBS and incubated in $37^{\circ} \mathrm{C}$ for $10 \mathrm{mi}-$ nutes and analysed by FACScan The minimum number of 10,000 events was collected and Cell quest ${ }^{\circledast}$ software was used for analysis.

\subsection{Measurement of Intracellular Ionized Calcium (Ca $\left.{ }^{2+}\right)$}

Intracellular $\mathrm{Ca}^{2+}$ was determined using Fluo-3 AM staining by a FACScan HSVECs were treated with hypoxia for 48 hours followed by 24 hours reoxygenation either in the presence or absence of taurine. Control cells were incubated in normoxia condition without taurine. $1 \mathrm{ul}$ of $\left(2 \times 10^{5}\right)$ cells were washed once with buffer (10 mM Hepes, $5 \mathrm{mM} \mathrm{KCl}, 145 \mathrm{mM} \mathrm{NaCl}, 1 \mathrm{mM} \mathrm{MgCl}, 10 \mathrm{mM}$ Glucose, $1 \mathrm{mM} \mathrm{CaCl}_{2}, \mathrm{pH}$ 7.4) and resuspended in $100 \mu \mathrm{l}$ buffer. After adding $0.42 \mu \mathrm{l}$ of Fluo-3 AM (1.0 mM in DMSO with 1\% pluronic F-127), cells were incubated at room temperature for $45 \mathrm{~min}$. LMCF intensity of stained cells was detected with FL1. The minimum number of 10,000 events was collected and Cell quest ${ }^{\oplus}$ software was used for analysis.

\subsection{Western Immunoblotting}

HSVECs were treated with $300 \mu$ lysis buffer ( $50 \mathrm{mM}$ Tris-HCL, $150 \mathrm{mM} \mathrm{NaCl}$, $5 \mathrm{mM}$ EDTA, $0.5 \%(\mathrm{w} / \mathrm{v})$ sodium deoxychlolate, $0.5 \%(\mathrm{v} / \mathrm{v})$ triton X-100, $\mathrm{pH} 7.5)$ for $45 \mathrm{~min}$ on ice. Segments of ileum were snap frozen in liquid nitrogen and stored at $-80^{\circ} \mathrm{C}$. Tissues were thawed, homogenized in PBS. Lysed samples were centrifuged at $12,000 \mathrm{rpm}$ for 10 minutes at $4^{\circ} \mathrm{C}$. Protein concentration was quantified using a BCA assay kit. The final protein concentration of samples was adjusted to $200 \mu \mathrm{g} / 100 \mu \mathrm{l}$ and the samples were then suspended in SDS-glycerol loading buffer ( $\mathrm{pH} 6.8,62.5 \mathrm{mmol} / \mathrm{L}$ Tris, $2 \%$ SDS, 10\% glycerol, 5\% mercaptoethanol, $0.01 \%$ bromophenol blue). Protein was denatured at $100^{\circ} \mathrm{C}$ for 10 minutes and separated by $12 \%$ SDS-PAGE with $20 \mu \mathrm{g}$ of total protein loaded per lane. Proteins were then transferred to a nitrocellulose membrane and labeled with a primary monoclonal antibody, mouse antihuman IgG1, specific for the eNOS. After the secondary monoclonal antibody was added, goat antimouse IgG1 conjugated with horseradish peroxidase and the immunoblots were developed using Super Signal West Pico Chemiluminescent substrate and visualized by exposure of X-ray film.

\subsection{Laparotomy, with Coeliac and Superior Mesenteric Ischemia}

Adult male Sprague-Dawley rats weighing 280 - $350 \mathrm{~g}$ were randomized into one of three groups: Control (sham I/R), I/R or taurine $+\mathrm{I} / \mathrm{R}$. They were not allowed solid food, but had free access to water $12 \mathrm{~h}$ prior to the experiment. For the intestinal permeability assay taurine @ $200 \mathrm{mg} / \mathrm{kg} /$ day was given by gavage for 5 days prior to the experiment. For the examination of microvascular injury tau- 
rine was given through jugular vein as a bolus. The rat was anaesthetized with sodium pentobarbitone $(50 \mathrm{mg} / \mathrm{kg}$, ip.) and following anaesthesia, a tracheotomy was performed to facilitate breathing during the experiment. The right jugular vein was cannulated for taurine (200 $\mathrm{mg} / \mathrm{kg}$ body weight) or saline administration. After midline laparotomy, the coeliac and superior mesenteric vascular pedicle was isolated near their aortic origins.

\subsection{Measurement of Intestinal Endothelial Barrier Permeability (Plasma to Lumen)}

After a midline abdominal incision, a segment of ileum (10 cm long), supplied by 3 - 4 blood vessel arcades was isolated from the remaining part of the intestine by incising the mesentery and the gut lumen was closed by tying it proximally and distally. Intestinal I/R was induced by separating and clamping the superior mesenteric and coeliac vascular pedicle with an traumatic clamp for 30 min, followed by reperfusion for $180 \mathrm{~min}$. Sham operation included separation of the pedicle without clamping, followed by $180 \mathrm{~min}$ sham reperfusion. After $\mathrm{I} / \mathrm{R}$, the aorta was cannulated at abdomen and perfusion with saline to remove the blood in the tissue. The tissue was further perfused at $40 \mathrm{ml} / \mathrm{min}$ using a peristaltic pump controller with physiologic saline containing $20 \mu \mathrm{g} / \mathrm{ml} \mathrm{FD} 4$ (4000 Dalton fluorescent dextran) for $5 \mathrm{~min}$. At the end of the experiment, the segment was filled up with $1 \mathrm{ml}$ saline, and then the samples were taken from the segment of ileum and perfusion solution and centrifuged at $10 \times \mathrm{g}$ for $10 \mathrm{~min}$ at $4^{\circ} \mathrm{C}$. After the plasma (perfusion solution) and luminal solution had been diluted (1:200), the concentration of FD4 was determined with the Perkin Elmer luminescence spectrophotometer (excitation wavelength: $485 \mathrm{~nm}$; emission wavelength: $535 \mathrm{~nm}$ ). In order to calculate intestinal permeability, the following equation was used:

Percentage ratio of plasma to lumen expression of FD4 = luminal FD4 concentration $(\mu \mathrm{g} / \mathrm{ml}) /$ perfusion solution FD4 concentration $(\mu \mathrm{g} / \mathrm{ml}) \times 100 \%$ [29].

\subsection{Measurement of Intestinal Epithelial Barrier Permeability (Mucosal-Serosal)}

Intestinal mucosal permeability was determined by using an everted gut sac method, as previously described [30]. Briefly, after I/R, the everted gut sac was prepared in ice-cold saline. One end of the gut segment was ligated with silk. The segment then was everted onto a thin metal rod, and the resulting everted gut sac was secured with silk tied to the grooved tip of a 2 -ml plastic syringe containing saline. The everted gut sac was distended gently by injecting $1.5 \mathrm{ml}$ of saline. The everted gut sac then was suspended in a $100-\mathrm{ml}$ beaker containing 80 $\mathrm{ml}$ of saline with added FD4 $(20 \mathrm{mg} / \mathrm{ml})$. The temperature of this solution was maintained at $37^{\circ} \mathrm{C}$. A $1 \mathrm{ml}$ sample was taken from the beaker before adding the everted gut sac to determine the initial external (mucosal surface) FD4 concentration. The everted gut sacs were incubated for $30 \mathrm{~min}$ in the saline solution containing FD4. The length and width of the gut sacs then were measured. The 
fluid in the everted gut sac was aspirated to determine FD4 concentration. The serosal and mucosal samples were centrifuged for $10 \mathrm{~min}$ at $10 \times \mathrm{g}$ and at $4^{\circ} \mathrm{C}$. Permeability was expressed as the mucosal-serosal clearance of FD4 calculated using the following equations

$$
\begin{gathered}
M=([\mathrm{FD} 4] \mathrm{ser}) \times 1.5 \\
F=M / 30 \mathrm{~min} \\
C=(F /[\mathrm{FD} 4] \mathrm{muc}) / A
\end{gathered}
$$

where $M$ is the mass (ng) of FD4 in the gut sac at the 30 min incubation period, [FD4] ser is the FD4 concentration in the serosal fluid aspiration from the sac at the end of the $30 \mathrm{~min}$ incubation period, $F$ is the flux of FD4 (in $\mathrm{ng} / \mathrm{min}$ ) across the mucosa, [FD4] muc is the FD4 concentration measured in the beaker at the beginning of the $30 \mathrm{~min}$ incubation period, $A$ is the calculated area (in $\mathrm{cm}^{2}$ ) of the mucosal surface, and $C$ is the clearance of FD4 $\left(\mathrm{nl} / \mathrm{min} / \mathrm{cm}^{2}\right)$ across the $\mathrm{mu}$ cosa.

\subsection{Myeloperoxidase Activity}

Myeloperoxidase activity, an index of PMN accumulation, was determined as previously described [31]. Briefly, a fragment of ileum that had undergone ischemia for $30 \mathrm{~min}$ and reperfusion for $180 \mathrm{~min}$ was removed and snap frozen in liquid nitrogen. Upon thawing, the tissues were weighed and then homogenised in solution $\mathrm{B}(10 \mathrm{ml})$, containing $0.021 \%(\mathrm{w} / \mathrm{v}) \mathrm{K}_{2} \mathrm{HPO}_{4}, 0.663 \%(\mathrm{w} / \mathrm{v})$ $\mathrm{KH}_{2} \mathrm{PO}_{4}$ and $0.5 \%(\mathrm{w} / \mathrm{v})$ hexadecyltrimethyl ammonium bromide in distilled water. The homogenates were freeze-thawed twice and centrifuged at $2000 \mathrm{rpm}$ for $10 \mathrm{~min}$. The supernatant was collected and assayed spectrophotometrically for MPO activity by adding $0.1 \mathrm{ml}$ of supernatant to $2.9 \mathrm{ml}$ of freshly prepared solution $\mathrm{C}\left(0.0105 \mathrm{~g} \mathrm{~K}_{2} \mathrm{HPO}_{4}\right.$ and $0.3315 \mathrm{~g} \mathrm{KH}_{2} \mathrm{PO}_{4}$ in $40 \mathrm{ml}$ of distilled water with $5 \mathrm{ml}$ of a $0.017 \%$ solution of dianisidine in methanol and $5 \mathrm{ml}$ of $0.006 \%$ hydrogen peroxide in distilled water to a total volume of $50 \mathrm{ml}$ ). The change in absorbance was monitored every minute for $10 \mathrm{~min}$, at a fixed wavelength of 460 nm (CPU 8720, UV/VIS Scanning Spectrophotometer, Philips, Eindhoven, Netherlands). One unit of MPO was defined as that degrading 1 micromole of peroxide/min at $25^{\circ} \mathrm{C}$ and calculated per gram of tissue using the following formula:

(Highest absorbance/10)/weight of tissue used/0.0113 = MPO/gram of tissue $0.0113=$ constant

\subsection{Tissue Wet: Dry Weight Ratio}

Intestinal wet: dry weight ratio was used as a measure of tissue oedema. A segment of intestine was harvested from each rat. The wet: dry weight ratio was calculated by weighing the freshly harvested intestinal tissue (wet weight), heating at $90^{\circ} \mathrm{C}$ in gravity convection oven for 72 hours and weighing the residuum that became constant (dry weight). 


\subsection{Measurement of Gut Blood Flux}

Gut blood flow was determined via a laser-doppler monitor and expressed as flux by placing a probe on the surface of gut and recording at 0 min (baseline), before reperfusion (30 min of ischeamia) and at $180 \mathrm{~min}$ after reperfusion, respectively.

\subsection{Intravital Microscopy}

A segment of mesentery was exteriorised and was observed with an inverted intravital microscope with an $40 \times$ objective lens. The mesentery was carefully positioned to minimize the influence of respiratory movements and was moistened with BBS (NaCl: $131.9 \mathrm{mM}, \mathrm{KCl}: 4.7 \mathrm{mM}, \mathrm{CaCl}_{2}: 2.0 \mathrm{mM}, \mathrm{MgSO}_{4}: 1.2 \mathrm{mM}$ and $\mathrm{NaHCO}_{3}: 20 \mathrm{mM}, \mathrm{pH} 7.4,36.5^{\circ} \mathrm{C}-37^{\circ} \mathrm{C}$ ). A video camera mounted on the microscope projected the images which were recorded on videocassette. Single unbranched venules with diameter of 20 - $35 \mu \mathrm{m}$ and length $>100 \mu \mathrm{m}$ were chosen for study. Rolling leucocytes was determined by measuring the time required for individual leukocyte to transverse a $100-\mu \mathrm{m}$ length of the venule expressed as $\mu \mathrm{m} /$ second. A leukocyte was considered to be adherent to the endothelial cell if it remained stationary for a period of 30 seconds or longer. Leukocyte adherence was expressed as number of leucocytes adhered to vessel wall per $100 \mu \mathrm{m}$ of venule. Leukocyte transmigration was expressed as the difference between the number of extravasated leucocytes in the field of view the beginning and at the end of the reperfusion period.

\subsection{Statistical Analysis}

Data is expressed as mean \pm standard error of the mean (SEM). Statistical difference between groups was determined using Data Desk ${ }^{\circledast}$ (version 4) software, univariate ANOVA with Scheffe's post hoc correction. Significant difference was established at $\mathrm{P}<0.05$.

\section{Results}

\subsection{HSVEC Cell Death}

48 hours of hypoxia followed by 24 hours of re-oxygenation significantly reduced HSVECs survival, as measured by flow cytometry $(49.4 \% \pm 2.76 \%$, control vs $73.5 \% \pm 1.13 \% \mathrm{I} / \mathrm{R} . \mathrm{P}<0.01)$. Supplementation with taurine $(0.5 \mathrm{mg} / \mathrm{ml})$ before or after hypoxia significantly attenuated I/R-induced HSVECs death (Tau + I/R: $71.6 \% \pm 2.91 \%$ and $\mathrm{I}+\mathrm{Tau} / \mathrm{R}: 64.7 \% \pm 4.01 \%, \mathrm{P}<0.01$ vs $\mathrm{I} / \mathrm{R}$ group) (Figure 1(a)). I/R resulted in significant increase in apoptosis of HSVEC as measured by Annexin V staining $(28.5 \% \pm 3.65 \%$, vs $14.7 \% \pm 1.67 \%$ Control). Taurine $(0.5 \mathrm{mg} / \mathrm{ml})$ added prior to or after hypoxia significantly attenuated $\mathrm{I} / \mathrm{R}$ induced HSVECs apoptosis $(14.8 \% \pm 1.74 \%$ Tau $+\mathrm{I} / \mathrm{R}$ group, $\mathrm{P}<0.01$ vs I/R group and $17.7 \% \pm 1.63 \%$ in $\mathrm{I}+\mathrm{Tau} / \mathrm{R}$ group, $\mathrm{P}<0.05$ vs $\mathrm{I} / \mathrm{R}$ group) (Figure 1(b)). Hypoxia followed by reoxygenation significantly induced HSVECs necrosis $(18.2 \% \pm 1.83 \%$ Vs $8.5 \% \pm 0.83 \%$ Control $)$. Administration of taurine $(0.5 \mathrm{mg} / \mathrm{ml})$ 


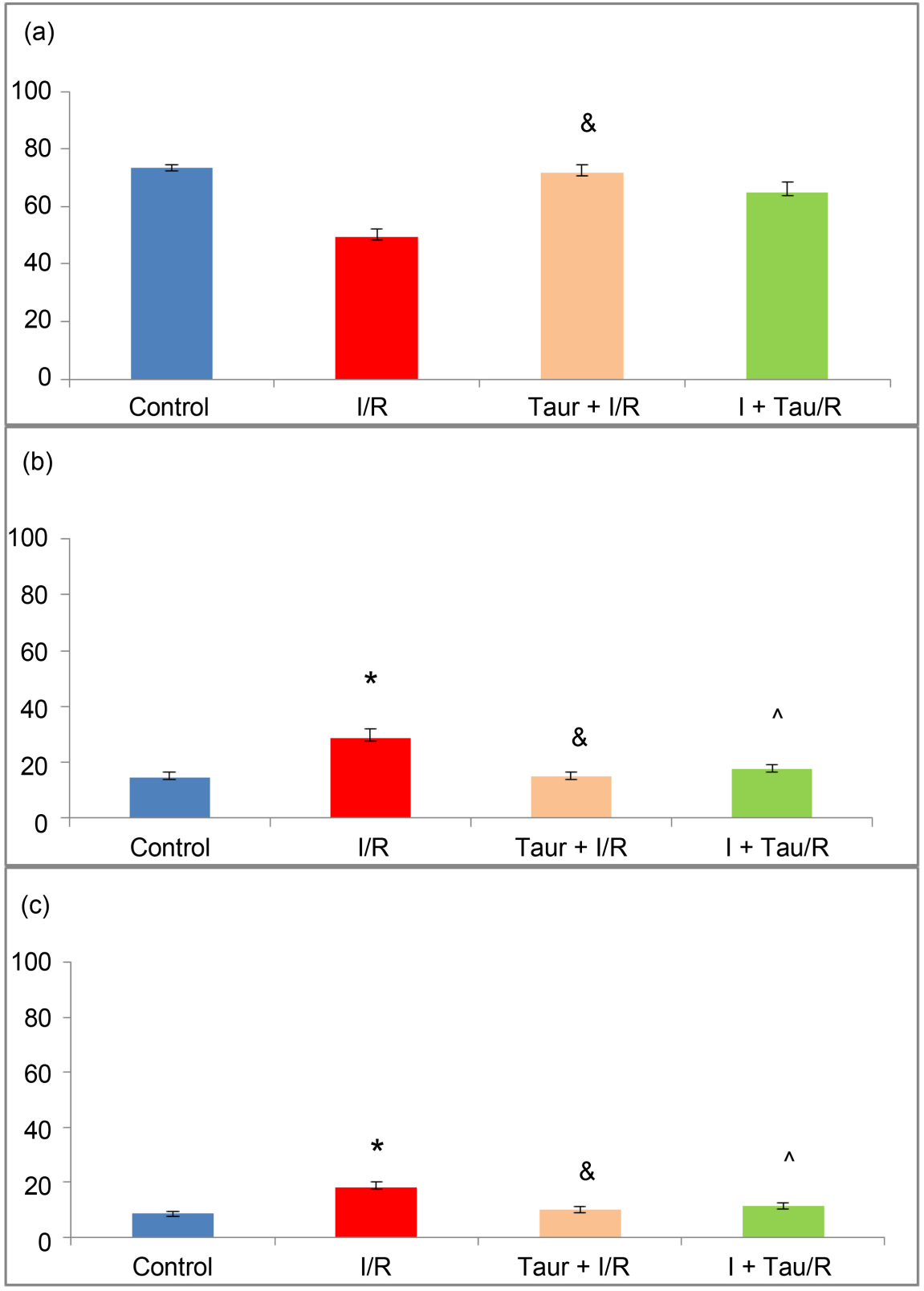

Figure 1. Ischaemia/Reperfusion results in HSVECs death. 48 hours of hypoxia followed by 24 hours of re-oxygenation significantly reduced HSVECs survival, as measured by flow cytometry. Supplementation with taurine $(0.5 \mathrm{mg} / \mathrm{ml})$ before or after hypoxia significantly attenuated I/R-induced HSVECs death (a). I/R resulted in significant increase in apoptosis. Taurine added prior to or after hypoxia significantly attenuated I/R-induced HSVECs apoptosis (b). Hypoxia followed by reoxygenation significantly induced HSVECs necrosis. Administration of taurine either before or after hypoxia significantly attenuated I/R-induced HSVECs necrotic death (c). Data were acquired as a percentage of cell population and are expressed as mean \pm SEM of 8 independent studies. A significant difference was established at $\mathrm{P}<0.05$, ANOVA with Scheffe's post hoc test. ${ }^{\star} \mathrm{P}<0.01$ vs Control. \&, $\wedge \mathrm{P}<0.01$ vs $\mathrm{I} / \mathrm{R}$ group.

either before or after hypoxia significantly attenuated I/R-induced HSVECs necrotic death (Tau + I/R: $9.7 \% \pm 1.47 \%$, and I + Tau/R: $11.2 \% \pm 1.31 \%$ ) (Figure $1(\mathrm{c}))$. 


\subsection{I/R Injury Induced ROS Production in HSVECs}

Intracellular ROS was significantly increased $(358.62 \pm 22.61 \mathrm{MCF}$ vs $245.24 \pm$ 18.25 control) following $\mathrm{I} / \mathrm{R}$. Administration of taurine $(0.5 \mathrm{mg} / \mathrm{ml})$ before or after 48 hours of hypoxia significantly reduced I/R-induced generation of ROS in HSVECs (Tau + I/R: $235.3 \pm 14.3$ and I + Tau/R: $279.3 \pm 8.12, \mathrm{P}<0.01$ and $\mathrm{P}<0.05$ vs I/R group, respectively) (Figure 2(a)).
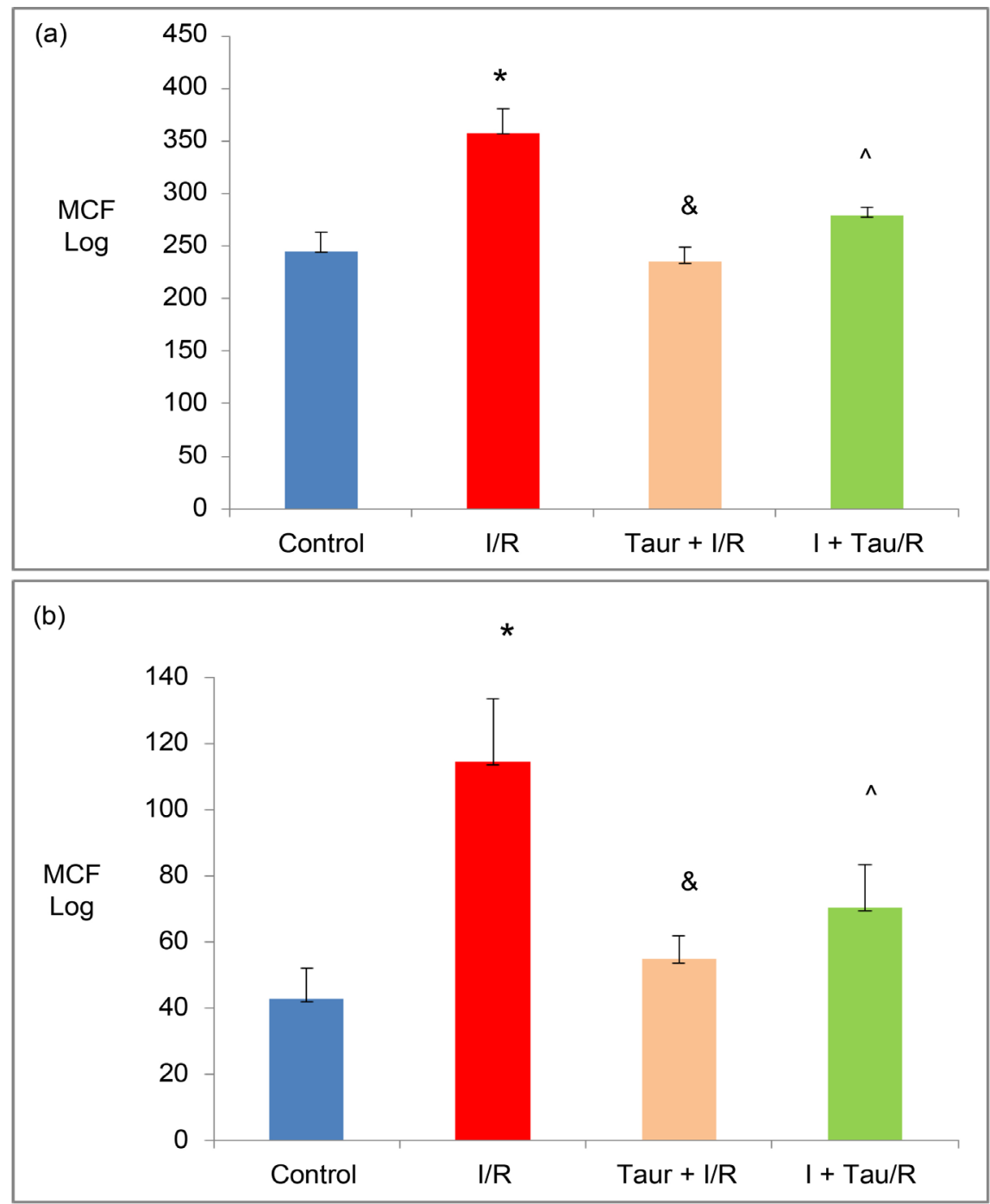

Figure 2. (a) I/R injury induce ROS production in HSVECs. Production of intracellular ROS was significantly increased following $\mathrm{I} / \mathrm{R}$ and administration of taurine $(0.5 \mathrm{mg} / \mathrm{ml})$ before or after the 48 hours of hypoxia significantly reduced I/R-induced generation of ROS in HSVECs. Data were acquired as Log Mean Chanel Fluorescence and expressed as mean \pm SEM of 4 independent experiments. Significant difference was established at $\mathrm{P}<$ 0.05 using ANOVA with post hoc test. ${ }^{\star}$ : $\mathrm{P}<0.01$ vs Control, $\&, \wedge$ : $\mathrm{P}<0.05$, Vs I/R group. (b) I/R injury induced intracellular calcium influx in HSVECs. I/R significantly elevated $\left[\mathrm{Ca}^{2+}\right]$ and administration of taurine $(0.5 \mathrm{mg} / \mathrm{ml})$ before or after 48 hours of hypoxia significantly reduced I/R-induced $\left[\mathrm{Ca}^{2+}\right]$ influx in HSVECs. (Data were acquired as Log Mean Chanel Fluorescence and expressed as mean \pm SEM of 5 independent experiments. Significant difference was established at $\mathrm{P}<0.05$ using ANOVA with post hoc test. @, ${ }^{*}$ : $\mathrm{P}<$ $0.01, \mathrm{I} / \mathrm{R}$ vs Control, Tau $+\mathrm{I} / \mathrm{R}$ and $\wedge$ : $\mathrm{P}<0.05, \mathrm{I} / \mathrm{R}$ vs $\mathrm{I}+\mathrm{Tau} / \mathrm{R}$. 


\subsection{I/R Injury Induced Intracellular Calcium Influx in HSVECs}

I/R injury significantly elevated intracellular calcium $\left[\mathrm{Ca}^{2+}\right]$ compared to control cells (114.3 $\pm 18.96 \mathrm{MCF}$ vs $42.7 \pm 9.54$ control). Supplementation with taurine $(0.5 \mathrm{mg} / \mathrm{ml})$ before or after the 48 hours of hypoxia significantly reduced I/Rinduced $\mathrm{Ca}^{2+}$ influx in HSVECs (Tau + I/R: $54.7 \pm 7.0$; I + Tau/R: $70.3 \pm 13.0$ ) (Figure 2(b)).

\subsection{IR Injury Downregulated eNOS Expression in HSVECs}

48 hours hypoxia followed by 24 hours of re-oxygenation decreased the EC expression of eNOS. The addition of taurine either before hypoxia or after hypoxia prevented this decrease. (Figure 3(a)). Western immunoblotting was performed on gut tissue exposed to ischemia for $30 \mathrm{~min}$ followed by $180 \mathrm{~min}$ reperfusion. eNOS expression is decreased in I/R gut. Administration of taurine eliminated this decreased eNOS expression (Figure 3(b)).

\subsection{Intestinal Barrier Injury}

Intestinal endothelial barrier integrity was evaluated by measuring percent ratio of the FD4 transfer from blood to the intestinal lumen (Control $n=6, I / R$ and $\mathrm{Tau}+\mathrm{I} / \mathrm{R} \mathrm{n}=7$ ). Permeability of FD4 from blood to the intestinal lumen significantly increased in after $30 \mathrm{~min}$ ischeamia followed by $180 \mathrm{~min}$ reperfusion, as evidenced by a marked increase in the flux of the fluorescent dye FD4 in I/R groups $(37.6 \% \pm 7.68 \%) \mathrm{p}<0.01$ vs. Control group $(6.0 \% \pm 1.23 \%)$. Treatment with taurine reduced the increase in the permeability after I/R $(11.4 \% \pm 2.29 \%)$. $\mathrm{P}<0.01$ vs. I/R group (Figure 4(a)) Intestinal epithelial barrier permeability was assessed by measuring clearance of FD4 from the intestinal mucosal to serosal (Control $n=5, I / R$ and Tau $+I / R ~ n=4)$. Permeability of FD4 crossing the intestinal epithelial barrier significantly increased in rats with $30 \mathrm{~min}$ ischeamia and $180 \mathrm{~min}$ reperfusion (I/R: $30.9 \pm 3.38 \mathrm{ng} / \mathrm{min} / \mathrm{cm}^{2}, \mathrm{p}<0.01$ vs. $18.08 \pm 1.57$ for Control) This I/R-induced increase in permeability was attenuated in rats treated with taurine. (19.7 $\pm 1.58, \mathrm{p}<0.05$ vs. I/R group) (Figure 4 (b)).

\subsection{Myeloperoxidase}

Sham operated rats $(n=6)$ had mesentery-associated MPO concentrations at $8.98 \pm 1.59 \mathrm{U} / \mathrm{g}$. Gut ischeamia/reperfusion increased these concentrations to $15.79 \pm 1.61 \mathrm{U} / \mathrm{g} 9(\mathrm{n}=6) .(\mathrm{P}<0.05$ vs Control group $)$. The administration of taurine $(\mathrm{n}=7)$ significantly decreased the MPO concentration to $9.35 \pm 1.45$ U/g. (p $<0.05$ vs. I/R group) (Figure $4(\mathrm{c})$ ).

\subsection{Tissue Oedema}

Wet and dry weight ratio of gut tissue in the animals with $\mathrm{I} / \mathrm{R}(\mathrm{n}=4)$ was significantly higher than in sham operated animals $(n=4)(5.26 \pm 0.54 \mathrm{p}<0.01$ vs. $3.69 \pm 0.15$ for Control). This increase in wet and dry weight of gut was not observed in those animals receiving taurine $(n=6)(3.65 \pm 0.29), p<0.01 \mathrm{vs.} I / R)$ (Figure 4(d)). 

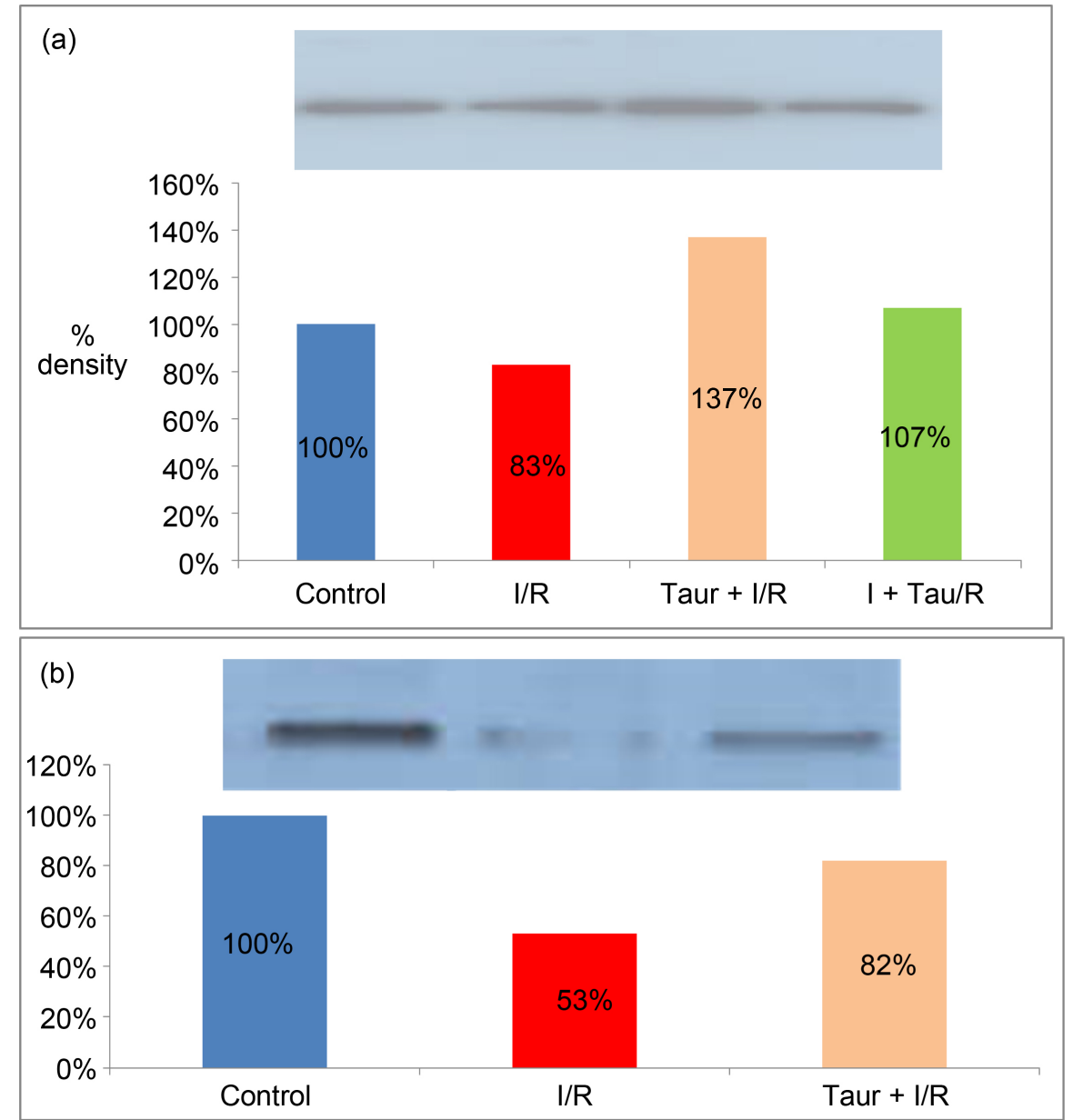

Figure 3. (a) IR injury downregulated eNOS expression in HSVECs. 48 hours of hypoxia followed by 24 hours of re-oxygenation down-regulated expression of eNOS in cultured HSVECs as determined by western immunoblotting. The addition of taurine either before hypoxia or after hypoxia prevented this decrease. The protein concentration per lane was $20 \mu \mathrm{g}$. The data are from 3 independent experiments. Lane 1: Control; lane 2: I/R; lane 3: Tau + I/R and lane 4: I + Tau/R. (b) IR injury downregulated eNOS expression in Gut Tissue. The protein concentration per lane was $20 \mu \mathrm{g}$. The data are from 3 independent experiments. Lane 1: Control; lane 2: I/R; lane 3: Tau + I/R and lane 4: I + Tau/R. 30 min of ischemia followed by $180 \mathrm{~min}$ reperfusion down-regulated expression of eNOS in gut tissue as determined by western immunoblotting. Taurine attenuated the decrease in eNOS expression induced by I/R.

\subsection{Gut Blood Flux}

The gut blood flux as assessed by Laser-Doppler (Figure 5) was significantly lower in animals with $30 \mathrm{~min}$ ischemia followed by $180 \mathrm{~min}$ reperfusion $(\mathrm{n}=4)$ $(43.24 \pm 2.47)$ as compared with control $(n=5)(79.05 \pm 3.78) . p<0.01$ vs. I/R group.

Taurine prevented this I/R altered gut blood flux $(\mathrm{n}=4)(69.20 \pm 4.16, \mathrm{p}<$ 0.05 vs. I/R group).

\subsection{Mesenteric Microvascular Parameters}

At baseline, there was no significant difference in leukocyte rolling velocity 


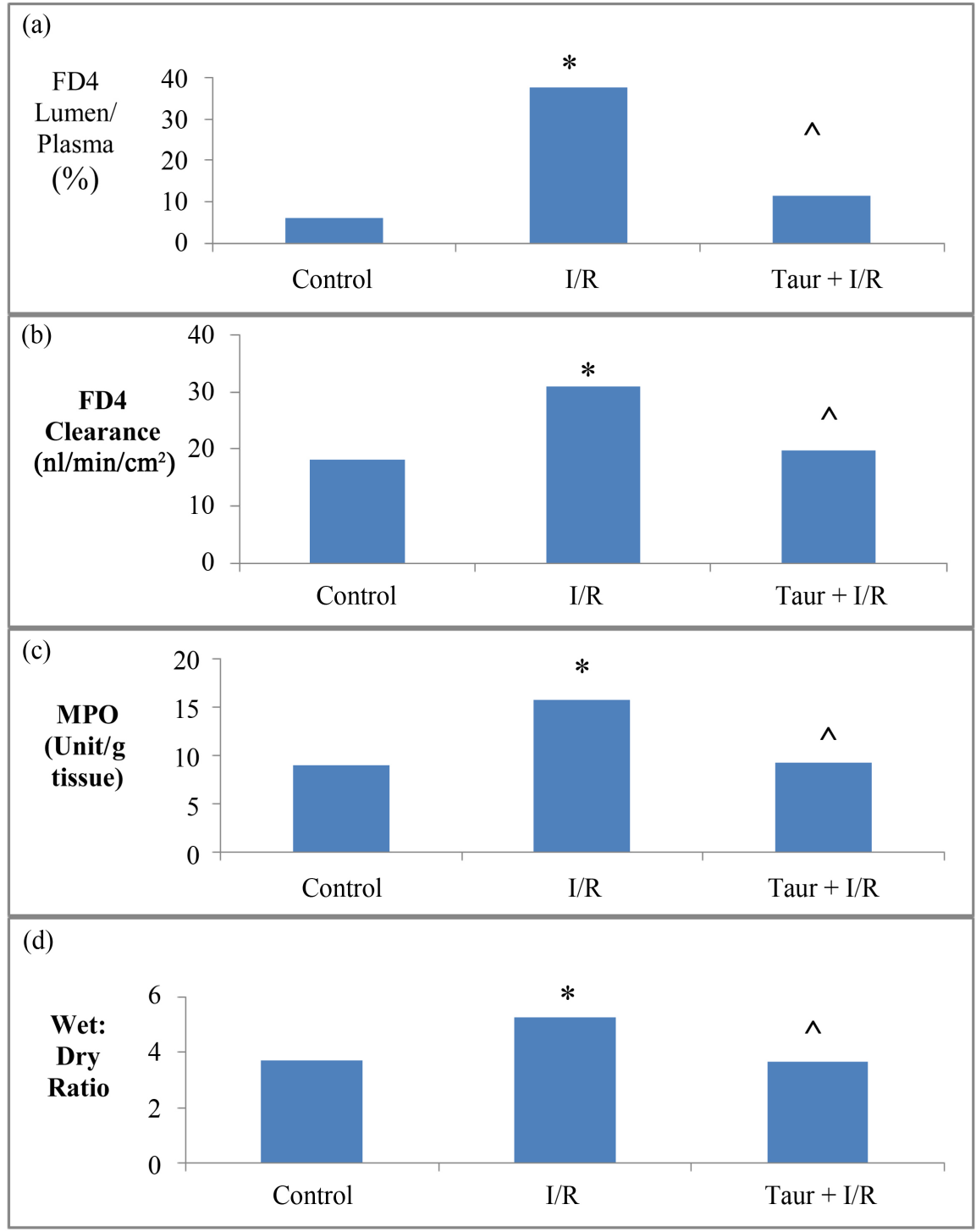

Figure 4. I/R-induced damage of intestinal barrier integrity. $30 \mathrm{~min}$ ischemia followed by 180 min reperfusion significantly increased endothelial leak as assessed by permeability of FD4 from blood to intestinal lumen measured by luminescence spectrophotometer. Taurine significantly attenuated this I/R-induced damage of endothelial barrier integrity. (a) I/R resulted in significant increase in intestinal permeability. Taurine significantly attenuated I/R-induced intestinal hyperpermeability. (b) I/R significantly increased gut tissue myeloperoxidase activity and taurine significantly decreases MPO activity (c). I/R resulted in significant increase in gut wet and dry weight radio and taurine attenuated I/R-induced gut tissue oedema (d). Data are expressed as mean \pm SEM and significant difference was established at $\mathrm{P}<0.05$ using ANOVA with scheff post hoc test. ${ }^{*}, \wedge$ : $\mathrm{P}<0.05, \mathrm{I} / \mathrm{R}$ vs. Control and Taurine plus I/R, respectively.

between control $(51.57 \pm 2.78 \mu \mathrm{m} / \mathrm{s})$ vs. I/R $(48.48 \pm 2.64 \mu \mathrm{m} / \mathrm{s})$ vs. Tau $+\mathrm{I} / \mathrm{R}$ $(50.94 \pm 0.96 \mu \mathrm{m} / \mathrm{s})$. After ischemia for $20 \mathrm{~min}$, the rolling velocity (y-axis) per reperfusion interval (x-axis) for three experimental groups is represented in Figure $6(\mathrm{a})$. The sham group $(\mathrm{n}=6)$ shows consistent rolling velocity at all time intervals $(56.83 \pm 3.37,54.41 \pm 2.95$, and $53.40 \pm 2.82 \mu \mathrm{m} / \mathrm{s}$, respectively). In contrast, the $I / R$ group $(n=6)$ shows a significant decrease of rolling velocity at 


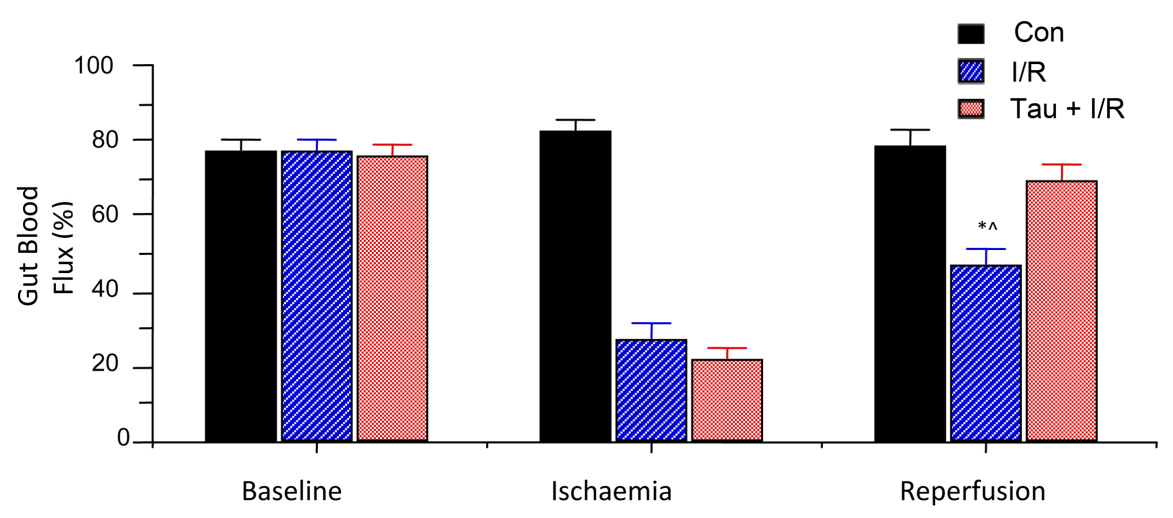

Figure 5. Effect of taurine on gut blood flux changing. The gut blood flux was significantly lower in animals after $30 \mathrm{~min}$ ischemia followed by $180 \mathrm{~min}$. Animals treating taurine at the time of reperfusion had significantly better blood flow after reperfusion compared to no treatment ${ }^{*}, \wedge: p<0.05$ vs. I/R group. As compared with control $p<0.01$ vs. I/R group.

$10 \mathrm{~min}, 30 \mathrm{~min}$ and $60 \mathrm{~min}(26.11 \pm 2.64,32.25 \pm 2.86$, and $29.09 \pm 3.78 \mu \mathrm{m} / \mathrm{s}$, respectively, $\mathrm{p}<0.01$ vs. Control group). Tau $+\mathrm{I} / \mathrm{R}$ group $(\mathrm{n}=5)$ maintains velocity at the corresponding time interval. $(44.58 \pm 3.92,53.37 \pm 4.62$, and $55.38 \pm$ $6.37 \mu \mathrm{m} / \mathrm{s}$, respectively, $\mathrm{p}<0.01 \mathrm{vs.}$ I/R group).

The quantity of adhesive leucocytes ( $\mathrm{y}$-axis) per reperfusion interval ( $\mathrm{x}$-axis) for the same experimental groups is represented in Figure 6(b). The Tau $+I / R$ groups were again very similar to the sham groups. Significantly less adhesion was observed at $30 \mathrm{~min}(2.67 \pm 1.31$, and $4.0 \pm 0.71 / 100 \mu \mathrm{m})$, and $60 \mathrm{~min}(3.33 \pm$ 1.61 , and $4.2 \pm 0.73 / 100 \mu \mathrm{m})$ when taurine treated and sham groups were compared with the $\mathrm{I} / \mathrm{R}$ group at $30 \mathrm{~min}(12.83 \pm 1.58, \mathrm{p}<0.0003$ vs. Control and Tau + $\mathrm{I} / \mathrm{R}$ group $)$, at $60 \mathrm{~min}(25.17 \pm 2.18, \mathrm{p}<0.00001$ vs. Control and Tau $+\mathrm{I} / \mathrm{R}$ group). The number of migrated leukocytes was less in the Tau $+I / R$ groups at, 30 , and $60 \mathrm{~min}(2.6 \pm 0.51$, and $3.8 \pm 1.11$, respectively) than in the $\mathrm{I} / \mathrm{R}$ group $(8.33 \pm 1.5$, and $11.5 \pm 1.63$, respectively, $\mathrm{p}<0.001$ vs. control and Tau $+\mathrm{I} / \mathrm{R}$ group) (Figure 6(c)).

\section{Discussion}

The intestinal mucosa is extremely sensitive to I/R injury which can tissue damage and remote organ failure. Hypoxia-mediated endothelial damage results in vascular dysfunction leading to leukocyte trafficking, tissue oedema and impaired vasomotor responses. Several studies have shown that EC are resistant to hypoxia, requiring a prolonged period of reduced oxygen to induce cell death [32]. Yet ischaemia/reperfusion (I/R) induces cell death in human umbilical vein EC (HUVEC), human coronary artery EC, and pulmonary microvessel EC [33] [34] [35]. In agreement with previous findings our study demonstrates that hypoxia resulted in significantly increased intracellular $\mathrm{Ca}^{2+}$ and ROS levels in HSVECs. Importantly taurine at a pharmacologically relevant dose before or after the hypoxic insult significantly attenuated the production of ROS and $\mathrm{Ca}^{2+}$ overloading in during reoxygenation. The continued dysfunction of endothelial 


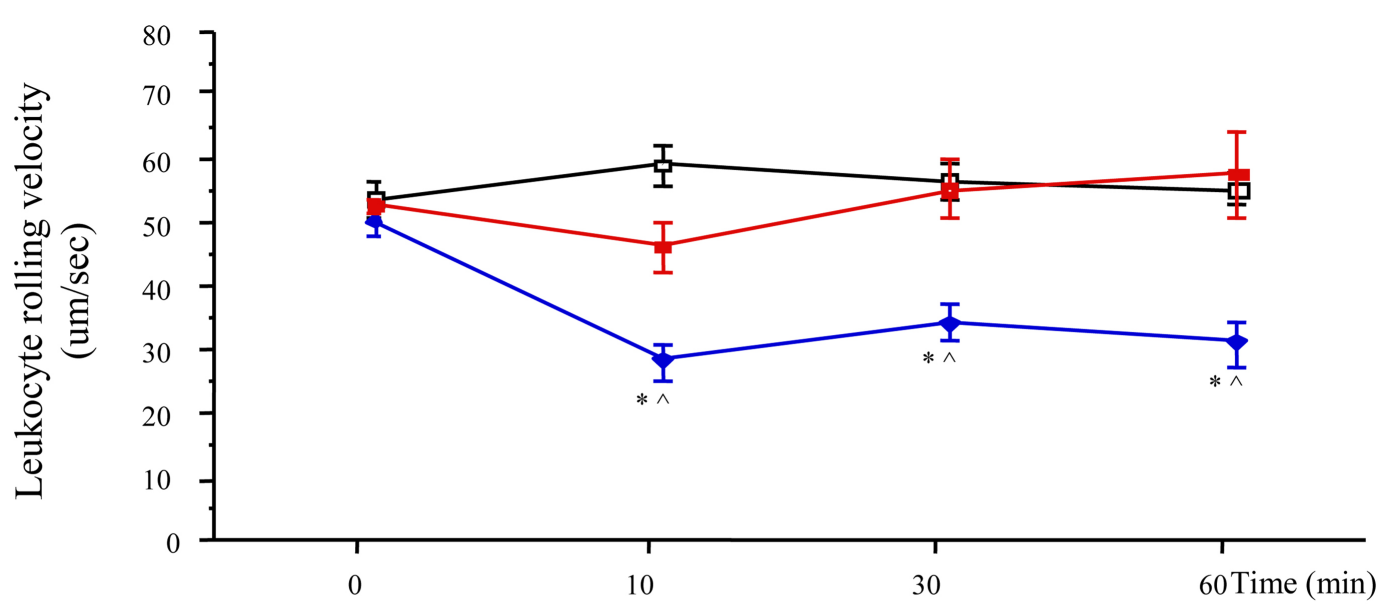

(a)

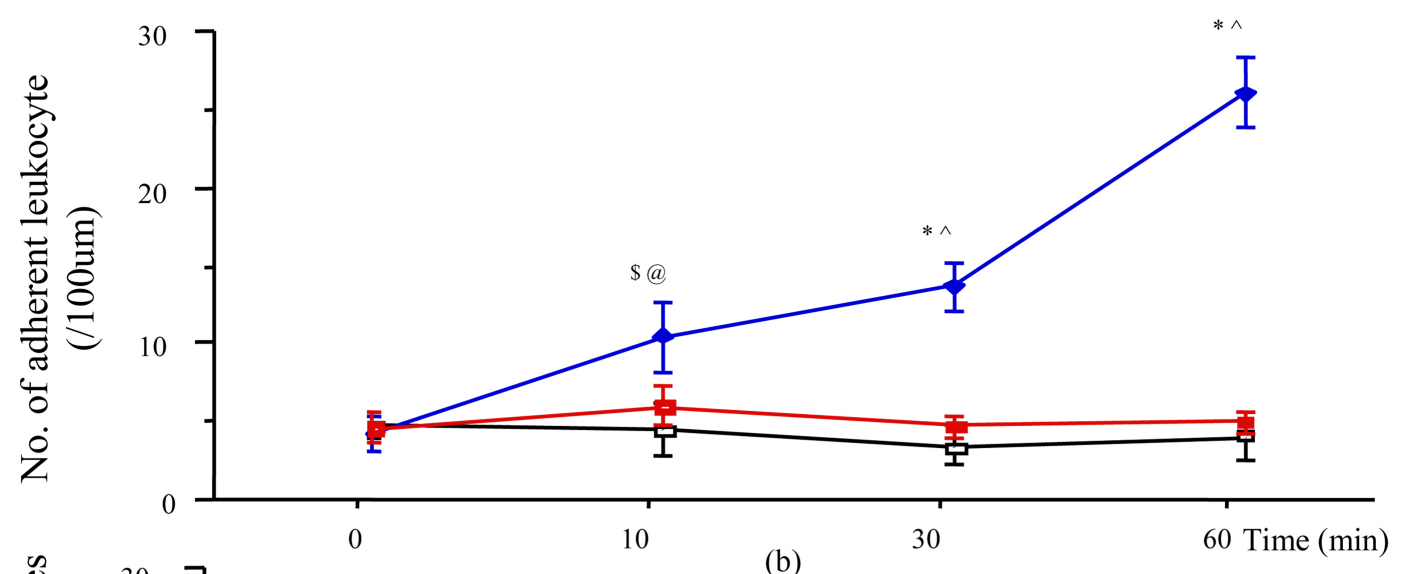

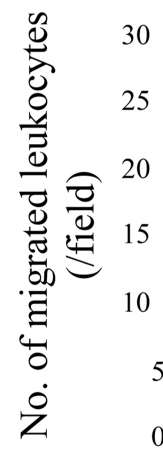

(b)

60 Time (min) 
hypoxia is not severe, glycolysis prevails during reoxygenation of hypoxiadamaged cells and glycolytic ATP drives cells into the apoptosis pathway. Conversely, in the absence of glycolytic ATP and lack of ATP production by defective mitochondria causes cells to undergo necrosis [37]. It is increasingly clear that mitochondria constitute an important component of the cell death machinery [38] and many mediators have been implicated in mitochondrial damage during I/R, including ROS, $\mathrm{Ca}^{2+}$ and tumour necrosis factor alpha (TNF- $\alpha$ resulting in EC death [2] [39] [40] [41] [42]. In this study I/R mediated injury resulted in a significant increase in EC apoptosis and necrosis. Administration of taurine prior to or after hypoxia significantly attenuated HSVEC cell death.

Nitric oxide (NO) at low concentrations is cytoprotective for endothelial cells modulating vascular tone attenuating increases in albumin leakage into venules, preventing platelet aggregation and neutrophil infiltration following I/R [23] [43] [44]. The production of NO is regulated by different isoforms of nitric oxide synthases (NOS) enzymes. Constitutive endothelial NOS (eNOS) is calciumdependent [45], mostly membrane bound and constantly present in endothelial cells producing low levels of NO from L-arginine upon cellular activation. The inducible isoform of NOS (iNOS) is not present in resting cells and expression requires stimulation by cytokines and/or lipopolysaccharide (LPS). Once expressed, iNOS generates large concentrations of NO ( $\geq 1 \mu \mathrm{mol} / \mathrm{liter})$, as found during inflammation, which has been implicated in both ROS and $\mathrm{Ca}^{2+}$ proapoptotic mechanisms [46] [47] [48] [49]. In these experiments I/R down-regulated eNOS expression in HUVECs resulting in a corresponding increase in cellular apoptosis and necrosis. Taurine preserved eNOS expression during I/R injury. In vivo ischemia for $30 \mathrm{~min}$ following by $180 \mathrm{~min}$ reperfusion decreased eNOS expression. Treatment with taurine preserved eNOS expression in gut tissue.

$\mathrm{I} / \mathrm{R}$ induced adverse alterations in intestinal permeability resulting in gut oedema in vivo, which was accompanied by leukocyte accumulation in the intestinal tissue. Intestinal endothelial permeability significantly increased after 30 min ischaemia followed by 180 min reperfusion, facilitating leucocyte transmigration from the blood to the intestinal lumen as evidenced by increased MPO activation. Intestinal epithelial barrier permeability significantly increased following I/R which could allow bacterial translocation. Treatment with taurine preserved both endothelial and epithelial barrier function permeability. I/R injury resulted in significant gut tissue oedema which was not observed in those animals receiving taurine. Taurine prevented I/R induced reduction of gut blood flux and prevented increased MPO activity. These results correlate well with recent findings from Sukhotnik et al. who demonstrated that taurine preserved mucosal parameters and intestinal histology following IR injury [50].

Leukocyte rolling is an essential prerequisite for adherence leading to tethering between the leucocytes and endothelial cells, allowing leucocytes to become activated [51]. Once adherent to vascular endothelial cells, leucocytes release ROS, TNF- $\alpha$, elastase, and collagenase which result in endothelial cell swelling 
and detachment from the basement membrane, compromised barrier function, protein extravasation, and interstitial edema [52] [53]. Following 10 minutes of reperfusion a significant decrease in leukocyte rolling speed was noted and after 30 and 60 min reperfusion, leukocyte adherence and migration significantly increased. Significantly less leucocyte adhesion and transmigration was noted in the taurine treated animals following reperfusion. It is known that attenuation of oxidative stress during simulated ischemia diminishes oxidative stress and cell death during the metabolic burst accompanying reoxygenation [54]. It has been suggested that taurine scavenges toxic hypochlorous acid and forms the less reactive metabolite, $\mathrm{N}$-chlorotaurine thus protecting from oxidant injury [55].

\section{Conclusion}

In conclusion, the main findings of this work are that taurine in clinically relevant doses effectively inhibits intestinal hyperpermeability and tissue edema and maintains normal microvascular function, following I/R of the coeliac and superior mesenteric vascular pedicle in rodents. Taurine can protect the gut barrier function during surgery and warrants further investigation as a peri-operative intervention, which can help to maintain gut barrier integrity and improve outcomes for patients undergoing surgery.

\section{Fund}

This work was funded by The Department of Surgery, Royal College of Surgeons in Ireland.

\section{References}

[1] Yellon, D.M. and Hausenloy, D.J. (2007) Myocardial Reperfusion Injury. The New England Journal of Medicine, 357, 1121-1135. https://doi.org/10.1056/NEJMra071667

[2] Saikumar, P., Dong, Z., Weinberg, J.M. and Venkatachalam, M.A. (1998) Mechanisms of Cell Death in Hypoxia/Reoxygenation Injury. Oncogene, 17, 3341-3349. https://doi.org/10.1038/sj.onc.1202579

[3] Kalogeris, T., Baines, C.P., Krenz, M. and Korthuis, R.J. (2012) Cell Biology of Ischemia/Reperfusion Injury. International Review of Cell and Molecular Biology, 298, 229-317.

[4] Varadarajan, R, Golden-Mason, L., Young, L., et al. (2004) Nitric Oxide in Early Ischaemia Reperfusion Injury during Human Orthotopic Liver Transplantation. Transplantation, 78, 250-256. https://doi.org/10.1097/01.tp.0000128188.45553.8c

[5] Parks, D.A. and Granger, D.N. (1986) Contributions of Ischemia and Reperfusion to Mucosal Lesion Formation. American Journal of Physiology, 250, G749-G753.

[6] Javadpor, M., Kelly, C.J., Chen, G., Stokes, K., Leahy, A. and Boucher-Hayes, D.J. (1998) Thermotolerance Induces Heat Shock Protein 72 Expression and Protects against Ischaemia-Reperfusion-Induced Lung Injury. British Journal of Surgery, 85, 943-946. https://doi.org/10.1046/j.1365-2168.1998.00722.x

[7] Neary, P. and Redmond, H.P. (1999) Ischaemia-Reperfusion Injury and the Systemic Inflammatory Response Syndrome. In: Grace, P.A. and Mathie, R.T. Eds., Ischaemia-Reperfusion Injury, Blackwell Science, Oxford, 123-136. 
[8] Tamion, F., Richard, V., Lyoumi, S., Daveau, M., Bonmarchand, G., Leroy, J., Thuillez, C. and Lebreton, J.P. (1997) Gut Ischemia and Mesenteric Synthesis of Inflammatory Cytokines after Hemorrhagic or Endotoxic Shock. American Journal of Physiology, 273, G314-G321.

[9] Liu, Z., Qin, H., Yang, Z., Xia, Y., Liu, W., Yang, J., Jiang, Y., Zhang, H., Yang, Z., Wang, Y. and Zheng, Q. (2011) Randomised Clinical Trial: The Effects of Perioperative Probiotic Treatment on Barrier Function and Post-Operative Infectious Complications in Colorectal Cancer Surgery-A Double-Blind Study. Alimentary Pharmacology \& Therapeutics, 33, 50-63.

[10] Gatt, M., Reddy, B.S. and Macfie, J. (2007) Bacterial Translocation in the Critically Ill-Evidence and Methods of Prevention. Alimentary Pharmacology \& Therapeutics, 25, 741-757. https://doi.org/10.1111/j.1365-2036.2006.03174.x

[11] Rodrigues, S.F. and Granger, D. (2010) Role of Blood Cells in Ischaemia-Reperfusion Induced Endothelial Barrier Failure. Cardiovascular Research, 87, 291-299. https://doi.org/10.1093/cvr/cvq090

[12] Arnould, T., Michiels, C., Alexandre, I. and Remacle, J. (1992) Effects of Hypoxia upon Intracellular Calcium Concentration of Human Endothelial Cells. Journal of Cellular Physiology, 152, 215-221. https://doi.org/10.1002/jcp.1041520127

[13] Kohli, V., Madden, J.F., Bentley, R.C. and Clavien, P. (1999) Calpain Mediates Ischemic Injury of the Liver through Modulation of Apoptosis and Necrosis. Gastroenterology, 116, 168-178. https://doi.org/10.1016/S0016-5085(99)70241-6

[14] Ali, M.H., Schlidt, S.A., Chandel, N.S., Hynes, K.L., Schumacker, P.T. and Gewertz, B.L. (1999) Endothelial Permeability and IL-6 Production during Hypoxia: Role of ROS in Signal Transduction. American Journal of Physiology, 277, L1057-1065.

[15] Yang, W. and Block, E.R. (1995) Effect of Hypoxia and Reoxygenation on the Formation and Release of Reactive Oxygen Species by Porcine Pulmonary Artery Endothelial Cells. Journal of Cellular Physiology, 164, 414-423. https://doi.org/10.1002/jcp.1041640222

[16] Zulueta, J.J., Sawhney, R., Yu, F.S., Cote, C.C. and Hassoun, P.M. (1997) Intracellular Generation of Reactive Oxygen Species in Endothelial Cells Exposed to Anoxia-Reoxygenation. American Journal of Physiology, 272, L897-902.

[17] Granger, D.N. and Korthuis, R.J. (1995) Physiologic Mechanisms of Postischemic Tissue Injury. Annual Review of Physiology, 57, 311-332.

https://doi.org/10.1146/annurev.ph.57.030195.001523

[18] Grishman, M.B., Hernandez, L.A. and Granger, D.N. (1989) Adenosine Inhibits Ischemia-Reperfusion-Induced Leukocyte Adherence and Extravasation. American Journal of Physiology, 257, H334-H339.

[19] Raschke, P., Massoudy, P. and Bercker, B.F. (1995) Taurine Protects the Heart from Neutriphi-Induced Reperfusion Injury. Free Radical Biology \& Medicine, 19, 461471.

[20] Wettstein, M. and Haussinger, D. (2000) Taurine Attenuate Cold Ischemia-Reoxygenation Injury in Rat Liver. Transplantation, 69, 2290-2296. https://doi.org/10.1097/00007890-200006150-00012

[21] Egan, B.M., Chen, G., Kelly, C.J. and Bouchier-Hayes, D.J. (2001) Taurine Attenuates LPS-Induced Rolling and Adhesion in Rat Microcirculation. Journal of Surgical Research, 95, 85-91. https://doi.org/10.1006/jsre.2000.6005

[22] Redmond, H.P., Wang, J.H. and Bouchier-Hayes, D. (1996) Taurine Attenuates Nitric Oxide and Reactive Oxygen Intermediate-Dependent Hepatocyte Injury. Archives of Surgery, 131, 1280-1288. 
https://doi.org/10.1001/archsurg.1996.01430240034004

[23] Wang, J.H., Redmond, H.P., Watson, R.W.G., Condron, C. and Bouchier-Hayes, D. (1996) The Beneficial Effect of Taurine on the Prevention of Human Endothelial Cell Death. Shock, 6, 331-338. https://doi.org/10.1097/00024382-199611000-00006

[24] Wu, Q.D., Wang, J.H., Fennessy, F., Redmond, H.P. and Bouchier-Hayes, D. (1999) Taurine Prevents High-Glucose-Induced Human Vascular Endothelial Cell Apoptosis. American Journal of Physiology, 277, C1229-C1238.

[25] Fennessy, F.M., Moneley, D.S., Wang, J.H., Kelly, C.J. and Bouchier-Hayes, D. (2003) Taurine and Vitamin C Modify Monocyte and Endothelial Dysfunction in Young Smokers. Circulation, 107, 410-415. https://doi.org/10.1161/01.CIR.0000046447.72402.47

[26] Nakashima, T., Seto, Y., Nakajima, T., Shima, T., Sakamoto, Y., Cho, N., Sano, A., Iwai, M., Kagawa, K., Okanoue, T. and Kashima, K. (1990) Calcium-Associated Cytoprotective Effect of Taurine on the Calcium and Oxygen Paradoxes in Isolated Rat Hepatocytes. Liver International, 10, 167-172. https://doi.org/10.1111/j.1600-0676.1990.tb00453.x

[27] Oriyanhan, W., Yamazaki, K., Miwa, S., Takaba, K., Ikeda, T. and Komeda, M. (2005) Taurine Prevents Myocardial Ischemia/Reperfusion-Induced Oxidative Stress and Apoptosis in Prolonged Hypothermic Rat Heart Preservation. Heart and Vessels, 20, 278-285. https://doi.org/10.1007/s00380-005-0841-9

[28] Gosling, M., Harley, S.L., Turner, R.J., Carey, N. and Powell, J.T. (1998) Human Saphenous Vein Endothelial Cells Express a Tetrodotoxin-Resistant, Voltaged Soldium Current. The Journal of Biological Chemistry, 273, 21084-21090. https://doi.org/10.1074/jbc.273.33.21084

[29] Cuzzocrea, S., Zingarelli, B., Costantino, G., Szabo, A., Salzman, A.L., Caputi, A. and Szabo, C. (1997). Beneficial Effects of 3-Aminobenzamine, an Inhibitor of Poly (ADP-Ribose) Synthease in a Rat Model of Splanchic Artery Occlusion and Reperfusion. British Journal of Pharmacology, 121, 1065-1074. https://doi.org/10.1038/sj.bjp.0701234

[30] Sims, C.A., Wattanasirichaigoon, S., Menconi, M.J., Ajami, A.M. and Fink, M.P. (2001) Ringer's Ethyl Pyruvate Solution Ameliorates Ischemia/Reperfusion-Induced Intestinal Mucosal Injury in Rats. Critical Care Medicine, 29, 1513-1518.

[31] Ivey, C.L., Williams, F.M., Collins, P.D., Jose, P.J. and Williams, T.J. (1995) Neutrophil Chemoattractants Generated in Two Phases during Reperfusion of Ischemic Myocardium in the Rabbit. Evidence for a Role for C5a and Interleukin-8. Journal of Clinical Investigation, 95, 2720-2728. https://doi.org/10.1172/JCI117974

[32] Stempien-Oterro, A., Karsan, A., Carol, J., Xiang, H., Eunson, T., Morrison, R.S., Kay, M., Winn, R. and Harlan, J. (1999) Mechanism of Hypoxia-Induced Endothelial Cell Death Role of p53 in Apoptosis. The Journal of Biological Chemistry, 274, 8039-8045. https://doi.org/10.1074/jbc.274.12.8039

[33] McQuillan, L.P., Leung, G.K., Marsden, P.A., Kostyk, S.K. and Kourembanas, S. (1994) Hypoxia Inhibits Expression of eNOS via Transcriptional and Posttranscriptional Mechanisms. American Journal of Physiology, 267, H1921-H1927.

[34] Li, D., Yang, B. and Mehta, J.L. (1999) Tumor Necrosis Factor- $\alpha$ Enhances Hypoxia-Reoxygenation-Mediated Apoptosis in Cultured Human Coronary Artery Endothelial Cells: Critical Role of Protern Kinase C. Cardiovascular Research, 42, 805 813. https://doi.org/10.1016/S0008-6363(98)00342-3

[35] Wiles, M.E., Hechtman, H.B., Morel, N.M.L. and Shepro, D. (1993) Hypoxia Reoxygenation-Induced Injury of Cultured Pulmonary Microvessel Endothelial Cells. Journal of Leukocyte Biology, 53, 490-497. 
[36] Amarente-Menes, G.P., Finucance, D.M., Cotter, T.G., Salvesen, G.S. and Green, D.R. (1998) Anti-Apoptotic Oncogenes Prevent Caspase-Dependent and Independent Commitment for Cell Death. Cell Death and Differentiation, 5, 298-306. https://doi.org/10.1038/sj.cdd.4400354

[37] Leist, M., Single, B., Castoldi, A.F., Kuhnlem, S. and Nicotera, P. (1997) Intracellular Adenosine Triphosphate (ATP) Concentration: A Switch in the Decision between Apoptosis and Necrosis. The Journal of Experimental Medicine, 185, 1481-1486. https://doi.org/10.1084/jem.185.8.1481

[38] Green, D.R. and Reed, J.C. (1998) Mitochondria and Apoptosis. Science, 281, 1309-1312. https://doi.org/10.1126/science.281.5381.1309

[39] McCord, J.M. (1985) Oxygen-Derived Free Radicals in Postischemic Tissue Injury. The New England Journal of Medicine, 312, 159-163. https://doi.org/10.1056/NEJM198501173120305

[40] Paradies, G., Petrosillo, G., Pistolese, M., Di Venosa, N., Federici, A. and Ruggiero, F.M. (2004) Decrease in Mitochondrial Complex I Activity in Ischemic/Reperfused Rat Heart: Involvement of Reactive Oxygen Species and Cardiolipin. Circulation Research, 94, 53-59. https://doi.org/10.1161/01.res.0000109416.56608.64

[41] Hardy, D.L., Clark, J.B., Darley-Usmar, V.M. and Smith, D.R. (1990) Reoxygenation of the Hypoxic Myocardium Causes a Mitochondrial Complex I Defect. Biochemical Society Transactions, 18, 549. https://doi.org/10.1042/bst0180549

[42] Nulton-Persson, A.C. and Szweda, L.I. (2001) Modulation of Mitochondrial Function by Hydrogen Peroxide. The Journal of Biological Chemistry, 276, 23357-23361. https://doi.org/10.1074/jbc.M100320200

[43] Kim, Y.M., Kim, T.H., Seol, D.W., Talanian, R.V. and Billiar, T.R. (1998) Nitric Oxide Supression of Apoptosis Occurs in Association with an Inhibition of Bcl-2 Cleavage and Cytochrome C Release. The Journal of Biological Chemistry, 273, 31437-31441. https://doi.org/10.1074/jbc.273.47.31437

[44] Michalk, D.V., Wingenfeld, P., Licht, C., Ugur, T. and Siar, L.F. (1996) The Mechanisms of Taurine Mediated Protection against Cell Damage Induced by Hypoxia and Reoxygenation. In: Huxtable, R.J., J. Azuma, Kuriyama, K., Nakagawa, M. and Baba, A., Eds., Taurine 2: Basic and Clinical Aspects. Advances in Experimental Medicine and Biology, Vol. 403, Springer US, 223-232.

https://doi.org/10.1007/978-1-4899-0182-8_24

[45] Suschek, C.V., Krischel, V., Bruch-Gerharz, D., Berendji, D., Krutmann, J., Kroncke, K.D. and Kolb-Bachofen, V. (1999) Nitric Oxide Fully Protects against UVA-Induced Apoptosis in Tight Correlation with Bcl-2 Up-Regulation. The Journal of Biological Chemistry, 274, 6130-6137. https://doi.org/10.1074/jbc.274.10.6130

[46] Kim, Y.M., Bombeck, C.A. and Billiar, T.R. (1999) Nitric Oxide as Bifunctional Regulator of Apoptosis. Circulation Research, 84, 253-256.

https://doi.org/10.1161/01.RES.84.3.253

[47] Dimmeler, S., Haendeler, J., Nehls, M. and Zeiher, AM. (1997) Supression of Apotosis by Nitric Oxide via Inhibition of Interleukin-1-Beta-Conventing Enzyme (ICE)-Like and Cysyeine Protease Protein(CCP)-32-Like Protases. The Journal of Experimental Medicine, 185, 601. https://doi.org/10.1084/jem.185.4.601

[48] Kim, Y.M., Talanian, R.V. and Billiar, T.R. (1997) Nitric Oxide Inhibits Apoptosis by Preventing Increases in Caspas-3-Like Activity via Two Distinct Mechanisms. The Journal of Biological Chemistry, 272, 31138-31148. https://doi.org/10.1074/jbc.272.49.31138

[49] Rossig, L., Haendeler, J., Hermann, C., Malchow, P., Urbich, C., Zeiher, A.M. and Dimmeler, S. (2000) Nitric Oxide Down-Regulates MKP-3 mRNA Level Involve- 
ment in Endothelial Cell Protection from Apoptosis. The Journal of Biological Chemistry, 275, 25502-25507. https://doi.org/10.1074/jbc.M002283200

[50] Sukhotnik, I., Aranovich, I., Ben Shahar, Y., Bitterman, N., Pollak, Y., Berkowitz, D., Chepurov, D., Coran, A.G. and Bitterman, A. (2016) Effect of Taurine on Intestinal Recovery Following Intestinal Ischemia-Reperfusion Injury in a Rat. Pediatric Surgery International, 32, 161-168. https://doi.org/10.1007/s00383-015-3828-3

[51] Lindbom, L., Xie, X. and Raud, J. (1992) Chemoattractant-Induced Leucocyte Adhesion to Vascular Endothelium in Vivo Is Critically Dependent on Initial Leucocyte Rolling. Acta Physiologica, 146, 415-421. https://doi.org/10.1111/j.1748-1716.1992.tb09442.x

[52] Zibari, G.B., Brown, M.F., Burney, D.L., Granger, D.N. and McDonald, J.C. (1998) Role of P-Selectin in the Recruitment of Leucocytes in Mouse Liver Exposed to Ischemia and Reperfusion. Transplantation Proceedings, 30, 2327-2330. https://doi.org/10.1016/S0041-1345(98)00641-1

[53] Moore, E.E., Moore, F.A., Franciose, R.J., Kim, F.J., Biffl, W.L. and Banerjee, A. (1994) The Postischemic Gut Serves as a Priming Bed for Circulating Neutrophils That Provoke Multiple Organ Failure. Journal of Trauma-Injury Infection \& Critical Care, 37, 881-887. https://doi.org/10.1097/00005373-199412000-00002

[54] Robin, E., Guzy, R.D., Loor, G., Iwase, H., Waypa, G.B., Marks, J.D., Vanden Hoek, T.L. and Schumacker, P.T. (2007) Oxidant Stress during Simulated Ischemia Primes Cardiomyocytes for Cell Death during Reperfusion. The Journal of Biological Chemistry, 282, 19133-19143. https://doi.org/10.1074/jbc.M701917200

[55] Gottardi, W., Hagleitner, M. and Nagl, M. (2005) N,N-Dichlorotaurine: Chemical and Bactericidal Properties. Archiv der Pharmazie, 338, 473-483. https://doi.org/10.1002/ardp.200500146

Submit or recommend next manuscript to SCIRP and we will provide best service for you:

Accepting pre-submission inquiries through Email, Facebook, LinkedIn, Twitter, etc. A wide selection of journals (inclusive of 9 subjects, more than 200 journals)

Providing 24-hour high-quality service

User-friendly online submission system

Fair and swift peer-review system

Efficient typesetting and proofreading procedure

Display of the result of downloads and visits, as well as the number of cited articles

Maximum dissemination of your research work

Submit your manuscript at: http://papersubmission.scirp.org/

Or contact fns@scirp.org 